\title{
The 2019 Thoracic Surgery Residents Association and Society of Thoracic Surgeons traveling fellowship: Experience at Toronto General Hospital
}

Chi-Fu Jeffrey Yang, MD

Since 2015, the Thoracic Surgery Residents Association (TSRA) and The Society of Thoracic Surgeons (STS) have afforded cardiothoracic surgical trainees the opportunity to visit and learn from renowned surgeons and centers (Table 1). ${ }^{1-3}$ This year, through the TSRA/STS traveling fellowship, I had the privilege of visiting the University of Toronto and Toronto General Hospital, with Gail Darling, $\mathrm{MD}$, as my host surgeon.

I arrived in November 2019 to a packed schedule and curriculum that Dr Darling had devised for me-one that included not only an opportunity to learn from her, but also from her Toronto colleagues. Every day was eyeopening and constructive. From Dr Darling, I learned her technique for Heller myotomy and saw how she performs completion pneumonectomies for recurrent lung cancer. From Dr Shaf Keshavjee, I learned his methods for performing tracheal resection, extrapleural pneumonectomy for metastatic thymoma, and lung transplant. From Dr Marc De Perrot, I learned his pleurectomy/decortication techniques for mesothelioma, as well as the details of the SMARTER (Surgery for Mesothelioma After Radiation Therapy using Extensive pleural Resection) trial (NCT04028570). With Dr Kazuhiro Yasufuku, I watched him perform a segment 8 segmentectomy and afterward reviewed video with him and received pointers for how to perform complex segmentectomies. In addition, I spent time in his Interventional Thoracic Surgery Suite learning endobronchial ultrasound. All of the Toronto faculty members were wonderful teachers: They were generous with their time and provided insightful answers to my many questions in the operating room.

Dr Yasufuku also kindly arranged for me to tour the University of Toronto's state-of-the-art thoracic surgery research laboratories. Dr Alexander Gregor, a resident physician and $\mathrm{PhD}$ student, described his research in sentinel lymph node imaging as he walked me through

From the Department of Cardiothoracic Surgery, Stanford University Medical Center, Stanford, Calif.

Disclosure: Author has nothing to disclose with regard to commercial support.

Received for publication Feb 9, 2020; accepted for publication Feb 23, 2020; available ahead of print March 12, 2020.

Address for reprints: Chi-Fu Jeffrey Yang, MD, Department of Cardiothoracic Surgery, Stanford University Medical Center, Falk Cardiovascular Research Center, 300 Pasteur Dr, Stanford, CA 94305 (E-mail: cjyang@post.harvard.edu).

J Thorac Cardiovasc Surg 2020;160:1408-9

$0022-5223 / \$ 36.00$

Copyright (c) 2020 by The American Association for Thoracic Surgery

https://doi.org/10.1016/j.jtcvs.2020.02.112

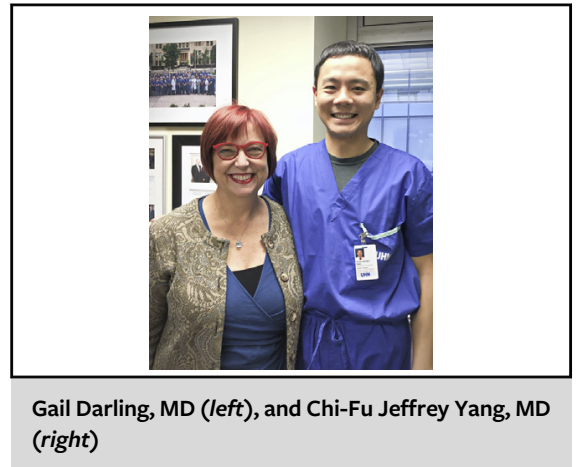

CENTRAL MESSAGE

Dr Yang describes his experience from the TSRA/STS traveling fellowship at Toronto General Hospital.

the maze of laboratories and facilities that comprise the research building. I was impressed by how each of the faculty members at Toronto from whom I learned was not only clinically outstanding, but also an accomplished, esteemed researcher in thoracic surgery.

In addition to spending time with the faculty, I also rounded with and learned from outstanding Toronto fellows who made me feel at home: Drs Mehdi Tahiri, Kalvin Lung, Benjamin Dunne, Dimple Brar, and Pablo Perez.

Being able to learn from Dr Darling was a true privilege. I first learned of her work as a medical student when she was spearheaded the landmark Z0030 trial. Since then, she has continued to shape and improve the field of thoracic surgery through her work in paradigm-shifting clinical trials, her leadership in the International Association for the Study of Lung Cancer, and her contributions to surgical education. Outside of the operating room, Dr Darling conferred valuable advice on how to start a thriving academic surgical practice and how to best impact the field. Receiving guidance from someone I so deeply respect was among the best parts of my traveling fellowship experience.

My time as a traveling fellow at the University of Toronto was incredibly memorable. I learned an enormous amount within the condensed time frame. I am grateful to the TSRA, the STS, Dr Darling, and the University of Toronto faculty for this wonderful experience. 
TABLE 1. Thoracic Surgery Residents Association and Society of Thoracic Surgeons Traveling Fellowship award recipients, their hosts, and study focus

\begin{tabular}{|c|c|c|c|}
\hline Year & Award recipient & Host surgeon & Study focus \\
\hline 2015 & $\begin{array}{l}\text { Arminder Jasser, MD } \\
\text { University of Pennsylvania }\end{array}$ & $\begin{array}{l}\text { Joseph Coselli, MD } \\
\text { Texas Heart Institute and Baylor College of Medicine }\end{array}$ & Aortic surgery \\
\hline 2016 & $\begin{array}{l}\text { Brian Mitzman, MD } \\
\text { University of Chicago }\end{array}$ & $\begin{array}{l}\text { Robert Cerfolio, MD } \\
\text { University of Alabama }\end{array}$ & Robotic thoracic surgery \\
\hline 2017 & $\begin{array}{l}\text { Taufiek Konrad Rajab, MD } \\
\text { Brigham and Women's Hospital }\end{array}$ & $\begin{array}{l}\text { Shaf Keshavjee, MD } \\
\text { Toronto General Hospital }\end{array}$ & Pediatric lung transplantation \\
\hline 2018 & $\begin{array}{l}\text { Heidi Reich, MD } \\
\text { Cedars-Sinai Medical Center }\end{array}$ & $\begin{array}{l}\text { Teresa Kieser, MD, PhD } \\
\text { University of Calgary }\end{array}$ & Total arterial grafting \\
\hline 2019 & $\begin{array}{l}\text { Chi-Fu Jeffrey Yang, MD } \\
\text { Stanford University }\end{array}$ & $\begin{array}{l}\text { Gail Darling, MD } \\
\text { University of Toronto }\end{array}$ & Thoracic oncology \\
\hline
\end{tabular}

\section{References}

1. Reich HJ, Kieser TM. The 2018 Thoracic Surgery Residents Association and Society of Thoracic Surgeons traveling fellowship: total arterial grafting in Calgary. $J$ Thorac Cardiovasc Surg. 2018;156:2235-6.
2. Jassar AS. Experience from the inaugural TSRA traveling fellowship award. $J$ Thorac Cardiovasc Surg. 2015;150:1424.

3. Rajab TK, Van Arsdell G, Keshavjee S. Experience from the Thoracic Surgery Residents Association traveling fellowship: adult and pediatric lung transplantation in Toronto. J Thorac Cardiovasc Surg. 2017;154:2153-4. 